\title{
THE EFFECT OF STRATEGIC ALLIANCES ON THE DEVELOPMENT OF AUTOMOTIVE INDUSTRY: THE CASE OF TURKEY
}

Ayşegül Samsunlu

Beykent University,

\author{
Ali Akdemir \\ Çanakkale Onsekiz Mart University
}

\begin{abstract}
Strategic alliances are formed in order to spread risk, increase market power, preempt resources, access new markets and gain organizational learning. Among the various functions, knowledge acquisition, transfer and generation of technology have been regarded as the primary motives of strategic alliances in certain industries especially highly technological industries.
\end{abstract}

The strategic alliances in the automotive sector have been formed among the companies that operate in four regions on the world. These regions are USA and NAFTA, European Union, Japan and Korea. GM and Saab have entered into a strategic alliance in 1990. GM and FIAT has formed a strategic alliance in 2001. During recent years, some alliances have been formed in China. FAW -Toyota and Zongfeng -Nissan are the two examples of these alliances.

The strategic alliances in the automotive sector in Turkey are like joint ventures. In other words, they are like partnering in the automotive industry. Koç Holding, has formed Ford Otosan A.Ş. and has manufactured the first passenger car, Anadol and later manufactured the passenger cars with the brand name Ford. Koç Holding also formed a strategic alliance with Fiat Auto Spa and founded Tofaş. Oyak-Renault has formed a joint venture with Renault and started to manufacture passenger cars. Sabancı Holding formed a joint venture with Toyota in 1990. In 2002, the ownership structure has changed. Toyota owned $90 \%$ and Mitsui owned 10\% of shares. In 1990s, Anadolu and Honda and Hyundai and Assan have formed similar strategic alliances.

In this paper, the developments in the passenger car industry which make up the most important part of the automotive industry in Turkey have been studied since 1960s. The strategic alliances and their impact on economic factors such as exports, labor, research and development has been studied by using the data avail- able about the sector.

Key words: Strategic alliances, automotive sector, exports, labor, research and development.

\section{INTRODUCTION}

The automotive industry is one of the most important sectors that have effect on the development of the economy of a country. Due to the increase in the use of passenger cars especially in the developed countries and recently all around the world there is an increase in the amount of manufactured cars and the number of exported cars.

According to the 2004 statistics of world figures, $80 \%$ of the passenger cars that have been manufactured are manufactured by the ten firms of the five industrialized countries. According to the statistics, these figures are as follows: USA: 11.989 .000 cars, Japan: 10.511.000 cars, Germany: 5.569.000 cars, China: 5.070.000 cars, France: 3.665.000 cars and South Korea: 3.469.000 cars. Turkey has the seventeenth position and the number of cars that have been manufactured is $823.000 .(\mathrm{OSD}, 2005)$

In Turkey, the development of the automotive industry has started in the 1950s after the introduction of the liberalized economy. In 1961, a car named "Devrim" which was a prototype was manufactured. In 1966, Anadol was manufactured and it was the first passenger car of Turkey. In 1969, Renault resumed its operations in Turkey. Tofaş started to manufacture cars in 1971. Finally in 1994, Toyota started to manufacture cars. As a result of the entry of the country into Customs Union, Hyundai-Assan and Anadolu-Honda started to manufacture cars in Turkey. The total number of cars that was manufactured in 2004 was 823.000. Export figure has been 320.321 in 2004 .

The strategic alliances in the passenger car industry in 
the real sense occur more often among the companies of countries like USA,European Union, Japan and Korea. General Motors and Toyota, Ford and Mazda, Chrysler and Mitsubishi have formed strategic alliances. (Camuffo and Volpato, 2002) During recent years, China has followed the path of these countries and strategic alliances have been established in the sector. FAW Toyota and Zongfeng Nissan have been formed as strategic alliances in China. (Lee and Fujimoto, 2003) GM and its Chinese partner, Shanghai Automotive Industry Corp, have formed a strategic alliance and established Wuling Company which manufactures small vans and buses. These are exported overseas. The Wuling business is the second largest in the Chinese small people-carrier market, after Changan Auto, a joint-venture partner of Ford Motor (Mackintosh, 2006).

In Turkey, there are examples of cooperations such as the ones between Koç and Ford, Koç and Fiat, Sabanc1 and Toyota, Assan and Hyundai, Anadolu and Honda. These strategic alliances have the characteristics of a joint venture. The companies have manufactured cars in Turkey and exported an important amount of their production overseas.

After Turkey has entered the Customs Union in 1996, the integration has started in the sector and the new strategic alliances such as Anadolu Honda and Hyundai Assan have been formed. After 1996, exports started increased in global markets.

In this paper the passenger car industry of the automotive sector in Turkey has been studied.

\section{LITERATURE REVIEW}

At the end of the 20th century, many changes have taken place in the social, economic, political and cultural areas, and these changes have affected countries, companies and individuals. These changes have resulted in the formation of a new world order. Globalization has brought with it a boom in the opportunities that cause competitive advantage. Strategic alliances and other forms of cooperation have increased among the companies around the world.

"Alliances are where the real growth is strategic alliances providing a synergy for partners in which two and two make at least five in revenues preferably more." (Drucker, 2005 )

The aims of strategic alliances are product differentiation. Reduction in development costs, optimization of manufacturing capacity,reduction in time to market goods and services, improving productivity. Speeding up the product development cycle, spreading the high cost of R\&D and leveraging know-how whereever.

Strategic alliances have been formed between firms on a national or international basis. These alliances range from relatively noncommittal types of short-term, project-based cooperation to more inclusive long-term equity-based cooperation namely mergers and acquisition, joint ownership, joint venture, formal cooperative, informal cooperative.

The strategic alliance is designed to allow both companies to better serve their customers on a global basis.

An alternative theoretical definition of strategic alliances has been provided by Contractor and Lorange. It is the degree of interdependency. One theoretical way to define strategic alliances is to look at the continuous scale between one hand, transactions on a frre market ("market") and on the other, total internalization ("hierarchy"). The institution is one of the following. Informal cooperative venture, Formal cooperative venture, Joint venture, Joint ownership and mergers and acquisitions (high interdependence) (Lorange and Ross, 1992)

There are rapid developments around the world. There is explosive growth of alliances over the last decade. The marketshare impact of inter-partner learning in alliances especially in the global auto industry is very important (Contractor and Lorange, 2002).

Joint venture is one form of strategic alliances. A joint venture is further defined as an affiliate where foreign equity ownership is between $10-90 \%$ an affiliate with foreign equity shareholding of more than $90 \%$ is considered to be a wholly-owned subsidiary (WOS). Over the past two decades, there has been an unprecedented change in the nature of global business environment. Contemporary multinational enterprises (MNEs) facing the challenges of an increasingly complex business environment have to rethink their strategies as well as their organizational structures in order to succeed in this global arena. These challenges play conflicting demands on managers. One response has been the creation of joint ventures (JVs). Joint Ventures have emerged in recent years as a popular strategy in an environment in which fast access to up-to-date technology and emerging markets is more critical than ever before ( Yoshino and Rangan,1995).

The decision to enter into a joint venture (or another form of cooperative strategy decision) is a key competitive strategy decision, but, despite its importance it 
has not been well understood. Managers need guidelines to cope with joint ventures if they expect to use this strategy affectively (Harrigan, 1986)

International corporate linkages are the diverse interorganizational arrangements created by firms based in different countries to obtain strategic advantage in their markets and environments. The predominant forms of International Corporate Linkages are licensing agreements, technological transfers and exchanges, research and developments arrangements and joint ventures (Auster, 1987).

The international equity joint venture is the dominant form of the various forms of FDI (Foreign Direct Investment) in Turkey A joint venture is international in dimension if at least one partner is outside the venture's country of operation. It is important that there is significant level of operation in more than one country (Geringer and Hebert, 1989)

The most important motives of Turkish firms in forming strategic alliance are; to gain an access to advanced technologies and management practices. The introduction of new products, government policies, globalization of markets and resource needs are also important. Since Turkish firms are not investing in $R \& D$ activities, joint $R \& D$ activities have not been evaluated as important even though it is very important issue for international strategic alliances (Erimez, 1998). However this has changed during recent years and Turkish firms utilize their own technology.

During the last decade, the auto industry has become global (Sturgeon and Florida, 2001; Humphrey, Leder and Salerno, 2000).

Thus mergers and acquisitions (M\&A) and strategic alliances in the automotive industry are not only means to reduce and share financial risks, but also devices for increasing knowledge bases and count on a wider set of organizational capabilities (Hagedorn and Doysters, 2002; Camuffo and Comacchio,1999).

One of the hallmarks of strategic alliances in the global arena is between Fiat and GM. Fiat and GM have signed a partnering agreement in 2001. The reasons for partnering can be characterized in four areas. First of all, "pursuing-where-you-sell" strategy. Secondly, widening of the product range in order to satisfy a highly fragmented and differentiated demand and take advantage of niche market opportunities. Thirdly, achieving cost savings in design (platforms), purchasing (modules and component sharing), and manufacturing (modularity and outsourcing). Lastly, reducing the risk associated with the enormous organizational and financial effort required by international strategies by transferring design and manufacturing responsibilities to suppliers (Camuffo and Volpato, 2002).

Hyundai, Mitsubishi and Daimler-Chrysler have formed a strategic alliance to set up a world car project. They jointly advance into the world markets and improve liquidity (Chung, 2001).

Globalization will continue increasingly in the automotive sector. While giant companies are reorganizing their structures according to global and geographical requirements, it is impossible for them to ignore the automotive sector in Turkey, which has fixed its deficiencies and developed and promoted its advantages. The most important indication of this fact is the competitive strength of the automotive sector in Turkey at a global level.

The automotive sector in Turkey was established in 1950s. Today it has become one of the driving sectors of the Turkish industry with its dynamic production structure, volume of trade and the employment and added value it has created. This process that has started in 1996 with the Customs Union has been initiated and improved by the intense integration by the global companies in Turkey and their partners cooperating in local production. That is why production methods and technologies applied in the automotive industry in Turkey reach the same level as those applied by the international parent companies. Investments towards new and current model vehicles production were encouraged; technology imports and foreign capital partnership were facilitated and supported.

As the world enters next century, the new business model has evolved from one of $100 \%$ control to include strategic alliances with a broad network of automotive business partners and suppliers. For example GM has created strategic alliances. It has created strategic alliances with Suzuki for small cars. It has created strategic alliance with Toyota for technology, Honda engines for Hummer, Fiat for regional dominance and Isuzu for diesel engines and trucks.

There are many strategic alliances in the automotive industry among the companies of industrialized nations. The alliances among Turkish automotive firms are not exactly in the same sense as the examples given from the international markets. It is an issue of discussion. The partnerships in Turkey are joint ventures in which the foreign partner provides the knowhow, research and development and licensing opportunities. 
The strategic alliances in the automotive industry in Turkey have utilized their activities during a period of import substitution until 1980s. The main goal has been to increase the amount of domestic production that has been protected by customs barriers. Since 1980, export-oriented industrialization has been encouraged and it has developed. After Turkey has entered into Customs Union in 1996, the existing firms and the new companies have realized the necessity to form strategic alliances in order to access to new technologies, production opportunities and research and development. This way, these companies could export in international markets and compete with the companies that import in the domestic market. In 1996, a new system has developed and this system has encouraged the spread of research and development activities and design processes. New models have been developed with the foreign partner in the sector.

\section{METHODOLOGY}

At the beginning of this section, important information has been provided about the companies that have formed strategic alliances in Turkey. The relationships among various variables have been studied by using the data available about the sector. As a result of these data graphs have been drawn and evaluations have been reached about the strategic alliances.

The data that have been used in the evaluation of passenger cars are obtained from the Association of Automotive Manufacturers and General Directorate of Foreign Investments of Treasury. The evaluations are presented as graphs. (AAM, 2005) (GDFI, 2005)

\section{Ford Otosan}

It has been founded as Otosan A.Ş., an assembler of Ford vehicles in 1959.Over the next 3 decades, the company has evolved into a complete manufacturer of commercial vehicles and Ford became 30\% shareholder in 1983. In 1998, a new era for Otosan has begun as Ford Motor Co.'S share in the company increased to $41 \%$ equal to that of Koç Holding. Later, the name of the company changed to Ford Otosan A.Ş.

In 1966, Anadol has been manufactured by Koç Holding. During later years, the company has begun to sell the passenger cars with the brand name Ford Otosan and Escord cars until 1990s. Since the company has not been successful in the sales of passenger cars, it has stopped the production of passenger cars.

\section{TOFAŞ}

TOFAŞ has been formed with a licensing agreement between Fiat and Koç Holding in 1965 after a negoti- ation stage between 1964 and 1965. TOFAŞ started to manufacture cars in 1971

TOFAŞ has now become a modern company with an annual manufacturing capacity of 250.000 vehicles. Different FIAT models are manufactured on the 4 production lines in the assembly section of the plant. The $\mathrm{R} \& \mathrm{D}$ center has been established in 1994. It is the largest research and development center. When Turkey entered the Customs Union the company shifted its strategy towards exports like its rivals. TofaşFiat has formed a new joint venture with French Peugeot Citroen Company.

\section{Oyak-Renault}

In 1969, Oyak has formed a strategic alliance with Renault, a French company. It has started production of passenger cars in 1971 The company has reached the highest number of cars in 1998. The shareholder structure is as follows: Oyak-Renault is $57 \%$-owned by Renault $43 \%$ by Oyak, the Turkish armed- forcespension fund.. Oyak-Renault is actually a regional production and export platform. Turkey is a strategic market for Renault where it keeps its leadership since 1998.

Oyak-Renault invests 100 million annually in Turkey. In 2006, \$250.000 has been invested for its new Clio platform. Renault Clio Hatchback which has been chosen as the best passenger car in Europe will be manufactured in Turkey. It will be exported from Turkey.

\section{Toyota}

Toyota has formed a joint venture with Sabanc1 Holding in 1990. Toyota Motor Manufacturing Turkey is an affiliated company of Toyota Motor Corporation, one of the big three automakers in the world. The manufacturing of passenger car started for the domestic market as in Adapazarı in 1994. TMMT has been restructured in 2000 for export business. In 2002, the ownership structure has changed. $90 \%$ of the shares is held by Toyota and $10 \%$ is owned by Mitsubishi. It has reached the highest number of cars during recent years. Since 2002, Toyota is not a joint venture. It is a wholly-owned subsidiary.

According to Mr. Toyota, the founder of the company, as a result of the developments in Turkish automotive industry, the company supports the suppliers in the market through issues like product development, production techniques and project management. Turkey provides numerous opportunities such as the cost of production, qualified and competitive workforce and 


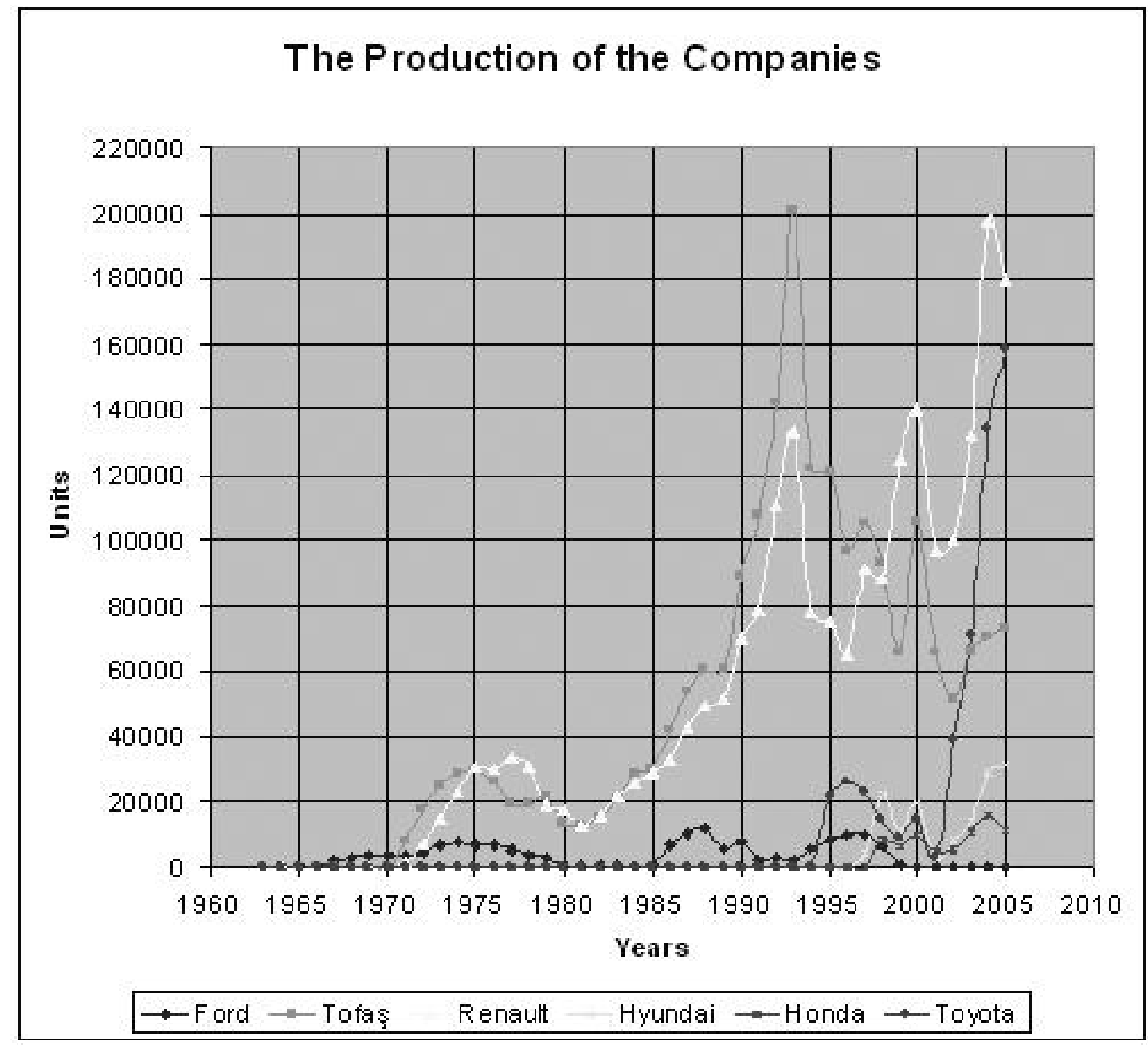

Figure 1: The total amount of production by the companies.

its closeness to many automotive markets. .

\section{Hyundai Assan}

Hyundai Assan started its production in 1990s. Hyundai Assan Otomotiv Co. has \%50-50 share by Hyundai Motor Company and Kibar Holding. Its factory has been opened in 1997.

Hyundai has announced to triple production in the next five years to 300.000 units and is investing $\$ 500$ million in the new platforms.

\section{Anadolu Honda}

Anadolu Honda started its production in 1990s. Currently $100 \%$ is owned by the Japanese company.

\section{Production of Companies}

The production figures of the companies in the passenger car industry are shown in Figure 1. The graphs below have been drawn by using the data that has been obtained from the Association of Automotive
Manufacturers.

Figure 1 shows that there is not an increase in the production figures on the dates on which the companies formed joint ventures. However, the rise in the amount of manufactured cars has continued until the economic crisis in 1994. As it has been explained above, the developments and manufacturing in the automotive industry have been through joint ventures as one of the form of strategic alliances. As it is seen in Figure 1, Ford, Tofaş and Renault have utilized the know-how that they have received from their foreign partner, in manufacturing passenger cars. This period is characterized as montage period because the supplier sector has not been developed and the companies imported parts of the cars. In the following years, the developments in the manufacturing of cars by these three firms have helped the improvement of the supplier side of the automotive industry. As the figure shows, Ford Company which is owned by Koç Holding, has stopped the production of cars in 1999 and started to manufacture minibuses and pickups. Later, Renault 
The total number and value of exports of the companies are in Figure 2.

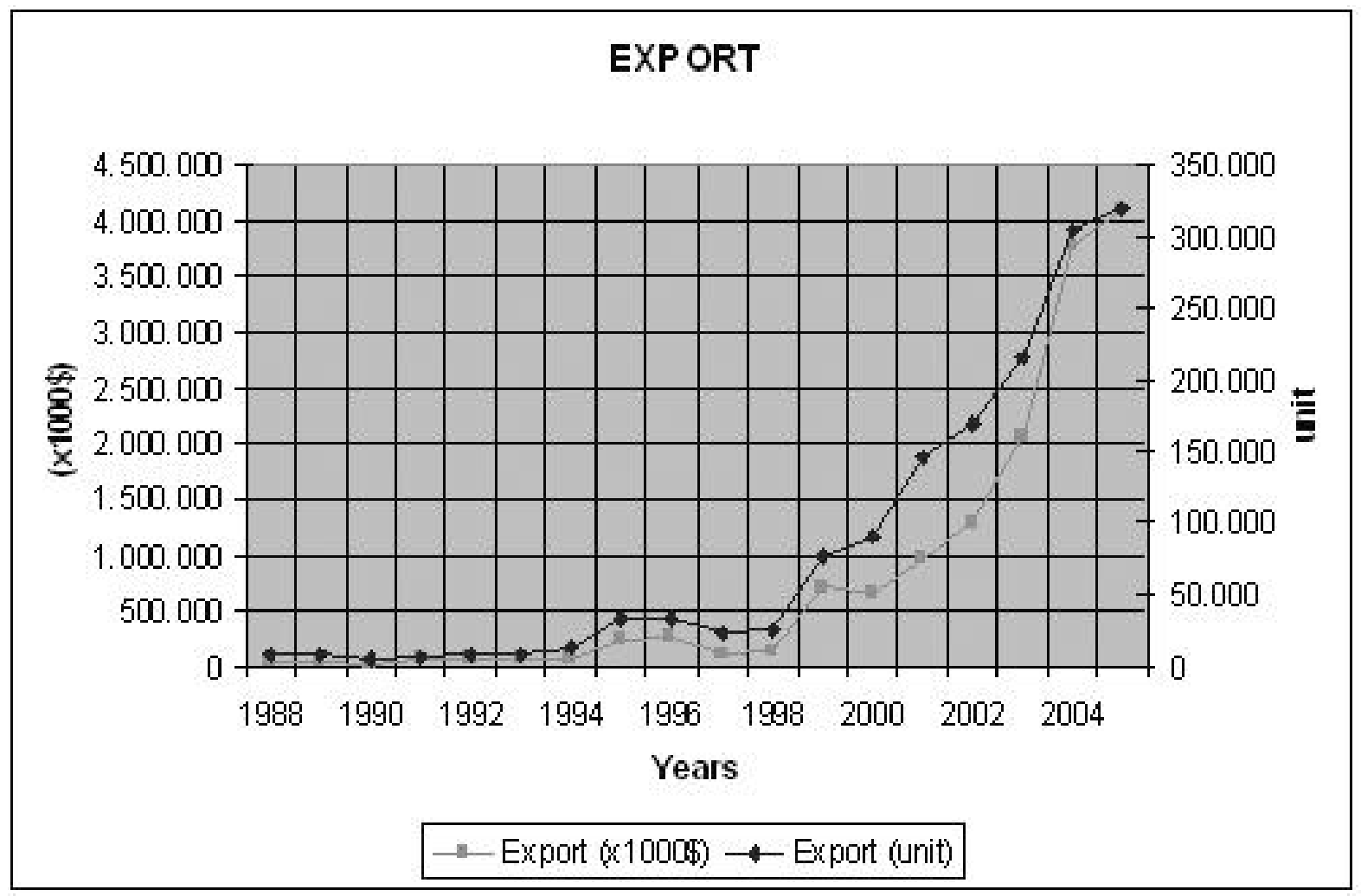

Figure 2: The total amount of exports in units and (x1000\$)

and Tofaş have increased their production. As the result of the Customs Union, Hyundai and Honda have entered the market and started to manufacture cars. During this period, the production figures of Renault continuously increased while those of Tofaş have declined sharply. In 2002, Sabanc1 Holding ended its partnership in the manufacturing of Toyota cars, and this was the end of the joint venture. The production figures rose astronomically after this development. As the figures in Table 1 that shows the export figures of companies in 2004 and 2005 is analyzed it is seen that Toyota and Renault have increased their exports and that they have exceeded other companies like Tofaş, Hyundai and Honda.

TABLE 1: Export Figures 2004-2005 (million USD) (OSD, 2006)

\begin{tabular}{|l|l|l|}
\hline & 2004 (USD) & \multicolumn{1}{|c|}{2005 (USD) } \\
\hline Toyota & 1.855 .886 .960 & 2.316 .921 .584 \\
\hline Oyak-Renault & 1.502 .586 .114 & 1.422 .601 .139 \\
\hline TOFAŞ* $^{*}$ & 821.696 .368 & 857.328 .710 \\
\hline Hyundai* $^{*}$ & 223.845 .398 & 210.375 .525 \\
\hline Honda Türkiye & 68.057 .862 & 40.001 .939 \\
\hline
\end{tabular}

*The number for these companies includes commercial vehicles.
When the export figures in terms of units and dollars are studied, it is seen that they have been low until the decision to enter the Customs Union. The figures have increased rapidly after 1998 .

\section{Exports-Research and Development of Companies}

The exports and research and development figures are in Figure 3.

\section{Figure 3: Exports and research and development of the companies in the sector.}

As a result of the increase in exports after 1996 and the increase in research and development premiums, the amount of research and development has increased. The automotive firms have realized the strategic importance of research and development activities and technological developments. Fiat Company has established the research and development center in Turkey in 1994. It is the largest R\&D department in the automotive companies. 


\section{LABOR - PRODUCTION}

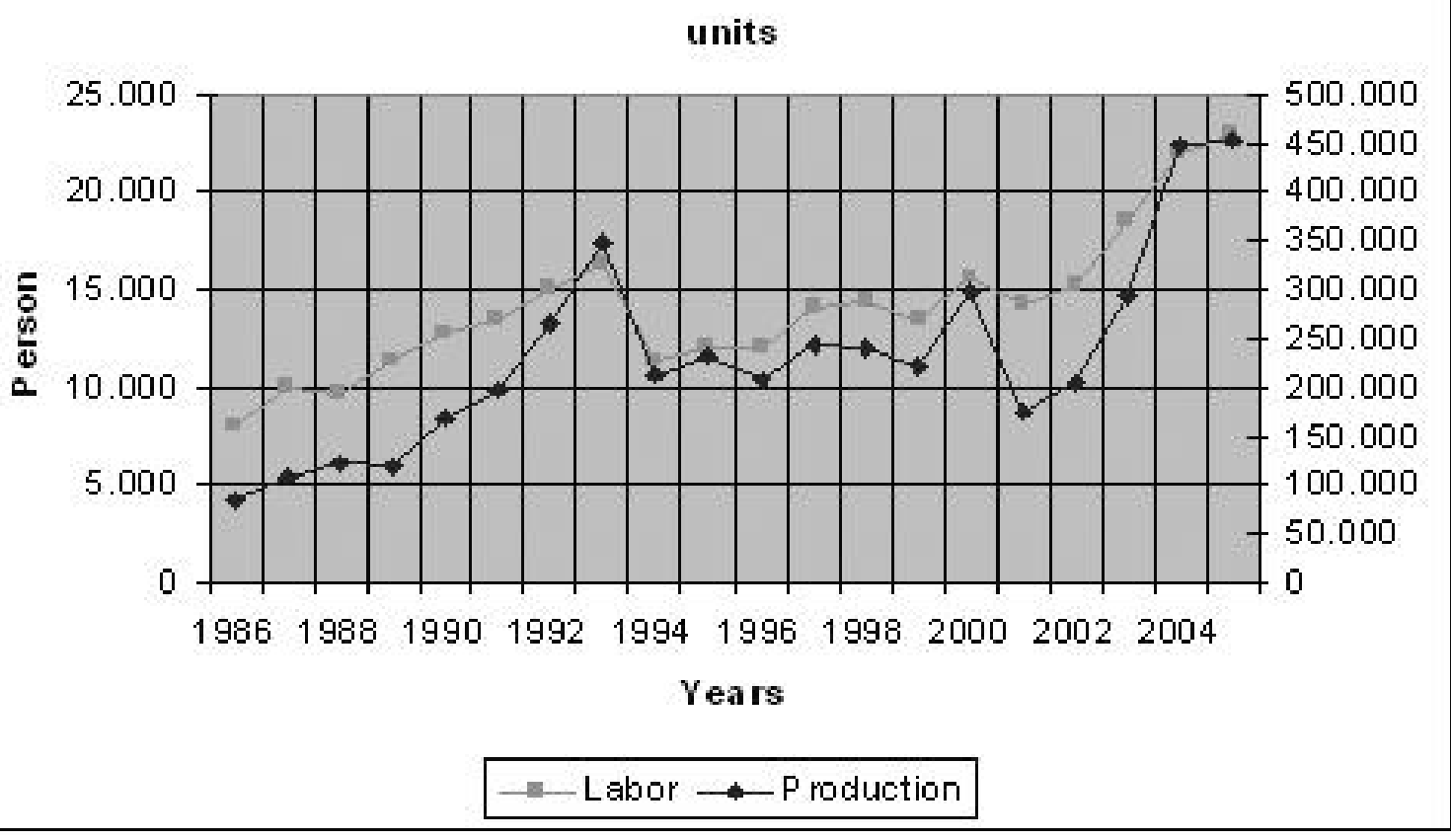

Figure 4: Labor and production in the sector.

\section{Labor-Production of Companies}

The increase in the amount of production in the automotive industry has caused an increase in the amount of labor. During the periods when the country is faced with economic crisis, the companies in the sector have chosen to retain their workers in their organizations.

\section{CONCLUSION}

As a result of globalization, firms around the world have formed strategic alliances. In Turkey, strategic importance has been given to the formation of alliances as part of the adaptation of the country's economy to the globalization process.

Automotive sector in Turkey is one of the main sources of the industry, and it holds the second place in exports. The first place is held by the textile sector. Automotive sector is one of the most advanced branches of Turkish manufacturing sector. With the growth rate and export capabilities it has achieved thus far, the sector has succeeded in becoming one of the few principle sectors of the Turkish economy and has managed to become on of the "target sectors". The automotive industry is in a continuous and dynamic change process due to the ever-changing conditions of the market and the intense competition on a global level. The automotive sector of Turkey follows global developments closely and is affected by them. While it is a very important sector, the export numbers are clear testimony of this success.

The automotive industry is a very important in the domestic market and now is at a position where it can compete in international markets. The export numbers are a clear testimony of this success. The total amount of exports in the passenger car industry has increased from 2.3 million USD in 2004 to 4.84 million USD İN 2005. The sector has a great export potential and has a very important role in Turkish economy.

The strategic alliances (joint ventures) that have been formed in the automotive industry have led to the development of the automotive industry and supplier industry in Turkey. At the beginning, the Turkish partner, did not have the adequate resources and technology so the foreign partner has been influential in providing production techniques and similar issues. During following years in which, Turkey has entered the Customs Union; some models have started to be manufactured only??? In Turkey and they have been exported overseas. Consequently rapidly increasing production brought with it the necessity to give emphasis to research and development. These strategic alliances have given special importance to technol- 
ogy. The amount of resources that has been utilized for $R \& D$ has increased. The encouragement premiums are also important in this process. The increase in production of passenger cars has led to an increase in labor.

As a result, it is seen that the production in the automotive industry has increased rapidly in 1990s. However the production figures of Tofaş Company have declined compared to those of Toyota and Renault. The export figures of these companies have similar results in 2004 and 2005.

According to the export figures, the amount of exports has increased after 1996 when Turkey has entered the Customs Union. The total amount of export figure has increased from 50.000 units in 1998 to 320.000 units in 2004. This improvement was the result of the strategic alliances that have been formed in the industry.

The increase in exports has led the companies to give importance to research and development activities. The companies in the sector aimed to take position in the world's automotive sector. The number of cars by person in Turkey is below most of the countries in the Balcan region and especially European countries. Turkey is expected to become more prosperous in the coming years. Therefore the number of people who want to purchase cars will increase in the future. The domestic demand will increase and the strategic alliances in the sector will be more effective. Currently, Turkey holds the sixteenth position in the number of production of passenger cars. As a consequence of the increasing impact of strategic alliances, eventually Turkey will reach the tenth position in the automotive industry around the world.

\section{DISCUSSION}

In this study, the data that has been collected has been evaluated. In the future, the companies' position in the sector should be evaluated by using questionnaires. Statistical analysis and matrix studies should be performed to study the impact of strategic alliances on factors like labor, research and development and production. In this paper, productivity, exports, production and exports have been studied.

It is very important to compare the performance of strategic alliances in other countries and Turkey. This analysis will help the academicians learn more about the position of Turkey in the automotive industry.

\section{REFERENCES}

Auster E.R, (1987) International Corporate Linkages Dynamic Form in Changing Enviroments, Columbia Journal of World Business, pp.3-6.

Camuffo,A. and Volpato,G., (2002) Partnering in the Global Auto Industry:The Fiat and GM Strategic Alliance, International Journal of Automotive Technology and Management 2, , pp.335-337.

Camuffo,A. and Comacchio, A. (1999) The fusion patents of lean practices:lessons from the European auto industry, in A.Comacchio, G.Volpato and A.Camuffo (Eds.) Automation in Automotive Industries Recent Developments, Berlin, Springer Verlang., Germany.

Chung, M.K. (2001) "Strategies Alliance and Restructuring for Survival: New Managerial Strategies of Hyundai" :"9th GERPISA International Colloquium on Reconfiguring the auto industry" 7-9 June 2001, France.

Contractor,F.J. and Lorange P.,(2002) Cooperative Strategies and Alliances in International Business, Elsevier Science, ISBN=0080441394

Erimez ,E., (1998), An Exploratory Study on Strategic Alliances in Turkey, PhD Dissertation,p..9, Boğaziçi University.

Geringer J.M and Hebert, L., (1989), Control and Performance of International Joint Ventures, Journal of International Business Studies, 20, pp.235-54.

Hagedoorn, J. and Duysters, G. (2002) "External sources of innovative capabilities: the preferences for strategic alliances or mergers and acquisitions ", Journal of Management Studies, March, Vol.39, No.2, pp.167-189.

Harrigan K.R., (1986) Managing for Joint Venture Success,Lexington Books, New York, USA.

Humphrey J, Leder Y. and Salerno, M.S., (2000) Global Strategies and Local Realities: Auto Industry in Emerging Markets, London, Mac Millan Pres Ltd.

Ercan, H., (2005) Otomotiv Sanayi - 2005 (Automotive Industry). Otomotiv Sanayi Derneği (Automotive Manufacturers Association), İstanbul .

Lee,C. and Fujimoto,T. (2003), The Chinese

Automobile Industry and the Strategic Alliances of 
China, Japan the US's Firms, Discussion Paper for International Motor Vehicle Program, MIT, USA.

Lorange,P and Roos, J., (1992), Strategic Alliances, Blackwell Publishers, USA

Mackintosh, J., (2006) "GM eyes China as base for exports to developing World" Financial Times, London, UK,.

Yoshino, M.Y. and Rangan, U.S. (1995), Strategic Alliances:An Entrepreneural Approach to Globalization Harvard Business School Press, Boston, MA.

General and Statistical Information Bulletin of Automotive Manufacturers Part1 (2005), (OSD) pp.14-24., Automotive Manufacturers Association, İstanbul

General and Statistical Information Bulletin of Automotive Manufacturers Part 2 (2005) (OSD), pp.1-7., Automotive Manufacturers Association, İstanbul

Turkish Time Sectors, (2004) TíM (A publishing of Turkish Exports Parliament), İstanbul

http//www.peter-drucker.com

Ward'S Auto World, (2005), Detroit,USA

General Directorate of Foreign Investment, (GDFI), 2005, Foreign Investment Report, Ankara .

http//www.osd.org.tr (2006) 